\title{
A Categorical Data Analysis on Financial Failures in Vietnam, 2007-2013
}

\author{
Quan Hoang Vuong ${ }^{1}$, Nancy K. Napier ${ }^{2}$, Tri Dung $\operatorname{Tran}^{3} \&$ Hong Kong T. Nguyen ${ }^{4}$ \\ ${ }^{1}$ Centre Emile Bernheim, Univesité Libre de Bruxelles, Belgium \\ ${ }^{2}$ College of Business and Economics, Boise State University, USA \\ ${ }^{3}$ DHVP Research \& Consultancy, Hanoi, Vietnam \\ ${ }^{4}$ Toan Viet Info Services Ltd, Hanoi, Vietnam \\ Correspondence: Quan Hoang Vuong, Centre Emile Bernheim, Université Libre de Bruxelles, CP114/03, 42 \\ Avenue F.D. Roosevelt, Brussels 1050, Belgium. E-mail: qvuong@ulb.ac.be
}

Received: June 22, 2013

doi:10.5539/ijbm.v8n18p87
Accepted: August 1, 2013

Online Published: August 20, 2013

\begin{abstract}
In this paper, we examined 256 cases of financial failure and fraud occuring during the recent Vietnam's chaotic years from 2007 to 2013, employing methods of categorical data analysis. Reported results suggest that the rent-seeking approach, or resource-based orientation, alone does not help explain the outcome of a business intention while the association between Orientation and Approach is the best-fit predictor. Rampant financial collapse not only increases the cost of funds but also erodes trust in the economy. Entrepreneurship development and creativity capacity building are necessary to improve socio-economic conditions and the environment. This work also introduces intuitive and cognitive factors to predict ex-ante outcome of a financing scheme.
\end{abstract}

Keywords: financial collapse, rent-seeking, creativity/innovation, economic transition

\section{Introduction}

Transition economies, like Vietnam, are facing challenging economic issues, due in part to emerging problems in their insecure and vulnerable financial systems (Vuong 2010; 2012). As Vietnamese became familiar with concepts of investments, they hope for returns that are good enough for compensating their improved risk appetite. In addition to willingness for a wide range of assets (Table 1), they were willing to tolerate much higher risks involved in their transactions and thus pursued different investment vehicles than what had previously been common.

Table 1. Typical Vietnamese household's preferable investments

\begin{tabular}{lcc}
\hline & Response & Percentage \\
\hline Gold & 3,052 & 28.3 \\
Foreign currencies (mostly U.S. Dollars) & 1,297 & 12.0 \\
Bank deposits & 3,250 & 30.2 \\
Land/Housing & 2,661 & 24.7 \\
Stocks & 520 & 4.8 \\
\hline
\end{tabular}

Source: Data were extracted from an online survey by VnExpress.net; the total number of responses is 10,780. (Accessed May 10, 2013).

Unfortunately, most of these approaches were in the so-called underground economy. Thus, casual investors had intended to act as "sharks" and made money, in fact, became "food" (Vuong, 2011). It appears that many households and 'quasi-entrepreneurs' acted as rent-seekers. They attempted to tap a growing base of resources, capital and physical, to enter into non-creative activities, as they simply tried to create 'money machines' (Vuong \& Napier, 2013). 
To gain a clearer sense of whether these assumptions hold, we review 256 cases of financial collapse to learn about the relationships between failures and frauds, and between collapses and the types of activities or orientation and business approach that firms pursue.

We question whether such significant relationships could serve to be a qualitative kind of predictor of failure and fraud, with which society does not have to wait until the collapses take place, when all one could do at best is collecting financial data, computing ratios and trying to learn about a past event.

\section{A Brieft Literature Review}

The literature in economics and finance argue a determination to pursue rent-seeking behaviors in the marketplace can happen in various stages of a business and can take various forms (Tullock, 1967; Krueger 1974; Tollison 1982). Rent-seeking and failures, in particular financial fraud, are both related hypothetically and empirically, especially in capital markets. Scharfstein and Stein (2000), for example, regarded the combination of rent-seeking and failure as 'the dark side of inefficient investments'. That explains why rent-seeking is costly to economies (e.g., Tullock 1967; Krueger 1974; Murphy, Shleifer \& Vishny 1993).

In the Vietnamese transition economy, rent-seeking has become rampant, characterized by relationship-based directed lending, allocation of scarce resources, granted monopolistic/oligopolistic business opportunities and other special treatments from authorities. Thus, it can hinder both creativity and entrepreneurship from flourishing (Napier, Dang \& Vuong, 2012; Vuong \& Napier, 2013). But when rent-seekers miscalculated their risks and returns, they suffered too, particularly in the Vietnamese M\&A market in recent years (Vuong, Napier \& Samson, 2013).

Zmijewski (1984) showed that market participants want methods for predicting financial fraud and failures. But the existing habits confine practitioners to technical estimations and financial ratios only. Nonetheless, Singleton and Singleton (2007) suggested that the existing mechanism of financial auditing has not been effective as hoped, and thus perhaps did not help much in detecting and preventing frauds. Even a famous model for predicting corporate bankruptcy, like the Altman Z-Score, only serves to be a research model (Moyer, 1977). Relying on financial ratios does not suffice as a good predictor either. As Ohlson (1980) concluded, technical details provided by ratios would depend on two facts: a) the event that has already happened; b) a strict condition of data sufficiency. In addition, Avlonitis, Papastathopoulou and Gounaris (2001) suggested that the relationships between the degree of innovativeness and performance are significant, but not always positively correlated.

With regard to examining conditions in Vietnam's transition turmoil, we follow Pressman (1998), who suggests that adequate attention should be made to strategic intents of the ventures with respect to both their orientation (on resources vs. market prospects) and approach taken in trying to fight for the profits they want (rent-seeking vs. creative performance/innovation). We also build upon previous research attempts in related business issues dealing with resource-based views toward entrepreneurship, creativity and financial performance, such as Napier, Dang \& Vuong (2012), Vuong, Napier \& Samson (2013), Vuong \& Napier (2013).

\section{Method of Analysis and Data Set}

This investigation used categorical data analysis (Agresti, 2002) to examine three hypotheses:

H1. Business managers' intention on Orientation (tapping resource or pursuing emerging opportunity) and Approach (rent-seeking vs. creativity) are interdependent.

H2. Structures of frequency distribution by 'Orientation $\times$ Approach' of fraud and failure are different.

H3. The association of Orientation and Approach best explains the outcome of a financing scheme.

\subsection{Method of Analysis}

a) Analysis of association vs. independence using contingency tables:

Contingency tables are comprised of count data in Table 2, appearing as joint frequency, denoted as $n_{i j}$ in a 2-way table. The value appears in a cell in the margins of the table is marginal frequency, which is a row/column total for one category of one variable. For each $2 \times 2$ table, row (column) total is noted $n_{i_{+}}\left(n_{+j}\right)$. Observed marginal probabilities then become $\mathrm{p}_{\mathrm{i}_{+}}=\left(\mathrm{n}_{\mathrm{i}^{+}} / \mathrm{n}_{++}\right)$for rows, and likewise for column. Total number of observations is denoted as $\mathrm{n}_{++}$.

Independence between categorical variables of count data is evaluated using odds ratio $(\theta)$, with a principle that if independence holds then true joint probability satisfies:

$$
\pi_{i j}=\pi_{i+} \pi_{+j}
$$


then the use of odds and estimated odds ratio for $2 \times 2$ table is relevant:

$$
\begin{gathered}
\text { Odds }=\pi /(1-\pi), \\
\text { Odds ratio }(\theta)=\left(p_{11} / p_{12}\right) /\left(p_{21} / p_{22}\right)=\left(n_{11} n_{12}\right) /\left(n_{21} n_{22}\right)
\end{gathered}
$$

Inference for odds ratio is made through the $\log$ odds ratio $\ln (\theta)$ and the corresponding confidence interval: $\ln (\theta)$ $\pm \mathrm{Z}_{\alpha} / 2$ (s.e.); where (s.e.) is computed standard error for $\ln (\theta)$ :

$$
\text { (s.e. })=\left[\left(1 / n_{11}\right)+\left(1 / n_{12}\right)+\left(1 / n_{21}\right)+\left(1 / n_{22}\right)\right]^{1 / 2},
$$

and $\mathrm{z} \sim \operatorname{iid} \mathrm{N}(0,1) ; \alpha$ (usually $5 \%)$ is the power of the test for determining the confidence interval of $(1-\alpha)$. The data set will be examined under the null hypothesis of independence $\left(\mathrm{H}_{0}\right)$, using a $\chi^{2}$-distributed likelihood ratio statistic, with $(\mathrm{I}-1)(\mathrm{J}-1)$ degrees of freedom:

$$
G^{2}=2 \Sigma_{I} \Sigma_{J} O_{i j} \ln \left(O_{i j} / E_{i j}\right)
$$

Also $\chi^{2}$-distributed Cochran-Mantel-Haenszel statistic is reported for evaluating $\mathrm{H}_{0}$, together with Fisher's exact test (see Agresti, 2002; Vuong, Napier \& Tran, 2013).

b) Method of logistic regression:

The logistic regressions take the generic form:

$$
\ln (\pi /(1-\pi))=\beta_{0}+\beta_{1} X_{1}+\beta_{2} X_{2}+\ldots+\beta_{k} X_{k}+\beta_{(k+1)} X_{1} X_{2}+\beta_{(k+2)} X_{1} X_{3}+\ldots
$$

Given the data set in Table 3 , the most complex specification has only 3 dichotomous predictor variables. The dichotomous response variable represents types of outcome, taking either 'failure' or 'fraud'.

An exploration into the overall goodness-of-fit is done by testing $\mathrm{H}_{0}: \beta_{1}=\beta_{2}=\cdots=0$, using the following $\mathrm{G}^{2}$ statistic:

$$
G^{2}=-2 \ln \left(L_{0} / L_{1}\right)=-2\left[\ln \left(L_{0}\right)-\ln \left(L_{1}\right)\right]
$$

where $\mathrm{L}_{0}$ represents numerical value of the likelihood function obtained from the data under the hypothetical $\pi$, and $L_{1}$ under the empirically estimated $\pi^{\wedge}$. This $G^{2}$ is $\chi^{2}$-distributed, with $(k+2)$ degrees of freedom.

\subsection{Data}

Each data point is classified into categories: type: fraud/failure; approach: rent-seeking/creativity; orientation: resources/market prospects. These are selected to reflect nature of a financial collapse during Vietnam's 2007-2013 transition turmoil.

Next, to understand the relationships between failure, fraud and organizational orientation (e.g, tapping out resources or seeking prospective markets), we prepared a structured data set as a frequency distribution (Table 2).

Table 2. Structured data on outcome

\begin{tabular}{llccc}
\hline & & \multicolumn{2}{c}{ Orientation } & \multirow{2}{*}{ Total } \\
\cline { 3 - 4 } & & Resource & Prospect & \\
\hline \multirow{2}{*}{ Failure } & Rent-seeking & 8 & 29 & 37 \\
& Creativity & 0 & 10 & 10 \\
\multirow{2}{*}{ Fraud } & Rent-seeking & 181 & 19 & 200 \\
& Creativity & 5 & 4 & 9 \\
& & 194 & 62 & 256 \\
\hline
\end{tabular}

Prior to 2007, the incidents of financial collapse were small in scale, simple business models, and almost solely within the informal economic sector. For instance, 'Hui' - an informal and primitive form of banking operation was typical and popular since late 1980s to 2000s. Individual members of a 'Hui' group commit to contribute a fix amount of money every term, often one week or one month. Each term, one member takes the sum of the contributed money to use in his or her business. Such rotation allows every individual to get his/her accumulated saving at once, instead of waiting for weeks and months. 'Hui' was interesting because it began as an innocent credit group or cooperatives but most ended as a fraud, not a business failure. When a 'Hui' group expanded, one member would be promoted to chair. The rotation kept continuing but the member, who is able to take the sum, would sell his/her right to the chair, very often, with a premium. The chair then would invested the sum $\mathrm{him} /$ herself or lend the money to other. In other words, the chair ran a banking business. If debtors were not able 
to repay, then the chair was in trouble. He/she tried to cover such failure by creating a sort of Ponzi scheme. Ultimately, some groups went from a loss of millions to tens of millions of U.S. dollar. Even so, the longevity of some 'Hui' groups was significant: a 40-member 'Hui' group in Ho Chi Minh City reportedly lasted for 26 years, from 1980 to 2006.

The notion of stock markets, of course, was quite new for the Vietnamese economy as it moved away from a planned focus. With little direct involvement or knowledge of how a stock market operated, then, many Vietnamese assumed that whatever they invested would go "up" in value, and as a result, they did not conceive or understand the concept of downside risk. The surge of the Vietnamese stock markets in 2006-2007 reflected that expectation and, as the economy boomed, people became overly confident of a bright future of the transition economy. They had reason to believe in such a positive trend as the Vietnam-Index increased by more than 200\% from March 2006 to March 2007, reaching its peak of 1,171 on March 12, 2007. Watching such a trend led many in Vietnam to believe that the exchange was a 'money machine.'

But soon, the public noticed that financial frauds were increasingly reported by the local media. The frauds also became larger, more complicated, and more often were related to formal credit system. For example, in some banks, the staff produced fake documents and cheated surveillance systems to embezzle their bank's money while convincing themselves that handsome profits would bring them large gains shortly and that they would safely return their "borrowed funds" to the bank. Others individuals advertised themselves as having important and strong relationships that allowed for purchasing stocks at prices far below market prices. Members of the public sometimes bought the privileges of being able to purchase stocks, and often did buy stock, but alas, never received it. Such examples of fraud began and grew in earnest as the turmoil escalated.

The period 2007-2013 is critical for Vietnam. Right after the stock market reached its peak, the emerging economy entered a turbulent period. Stock prices tumbled; the VN-Index plummeted to 287 in December 2008. Inflation roared to $23 \%$ in 2008 . Monetary policy tightened the market rate for credit to as much as $25 \%$. In addition to financial fraud, bankruptcies and business closures were prominent in the news. From early 2011 to the end of 2012, over 100,000 (mostly private) enterprises declared insolvency or quietly closed operations, accounting for between $15-25 \%$ of the enterprise population (Vuong and Napier, 2013).

Well-established incorporations, in both state and private sectors, were also facing severe problems, often financial collapse. Losses increased to tens and hundreds of millions, even billions of U.S. dollars. For example, Vietnam's major coffee exporter, Thai Hoa Co., was technically bankrupt with a debt of about $\$ 60$ million, while the state-owned shipbuilder Vinashin reportedly possessed a debt burden of approximately $\$ 4$ billion. Even financial tycoons, like Nguyen Duc Kien and Huynh Thi Huyen Nhu, were accused of financial wrongdoings that resulted in their creditors' losses of $\$ 370$ million and $\$ 250$ million, respectively, and the cases are under investigation. Increasing number of bankers and financiers has been arrested in recent years, also suggests more complicated financial frauds.

Next, to understand the relationships between failure, fraud and organizational orientation (e.g, tapping out resources or seeking prospective markets), we prepared a structured data set as a frequency distribution, given in table 3.

Intuitively, the frequency distributions shown in Table 3 tell us that the 'Rent-seeking $\times$ Resource' pair, in the 'Fraud' partial table, appears to be most 'influential' followed by 'Rent-seeking $\times$ Prospect' ('Failure' partial table). Additionally, it does not seem that 'Creativity' has a strong influence on explaining structure of the table. But more meaningful insights follow the empirical results provided in the next section.

\section{Emprical Results}

Results reported in this section are evaluated using $S A S{ }^{\circledR}$ Software. Firstly, test for independence between Orientation and Approach in the given data structure employs both $\chi^{2}$-distributed Pearson-statistic $\left(\mathrm{X}^{2}\right)$ and $\mathrm{G}^{2}$ with $d f=1$, and Fisher's exact test for right-sided probability, with results reported in Table 3 .

Table 3. Statistical independence check for data in table 2

\begin{tabular}{ccccc}
\hline & $\mathrm{X}^{2} ; \mathrm{G}^{2}$ & $\mathrm{p}$-Value & Fisher's (right-sided prob) & Independence \\
\hline $\mathrm{N}=256$ (No-split) & $256 ; 135(\mathrm{df}=1)$ & $<.0001$ & $4.2 \times 10^{-29}$ & Rejected \\
$\mathrm{N}=209$ (Frauds-only) & $209 ; 74(\mathrm{df}=1)$ & $<.0001$ & $5.7 \times 10^{-16}$ & Rejected \\
\hline
\end{tabular}


For both the sample, and sub-sample for fraud cases only, 'Orientation' and 'Approach' are statistically dependent. That means the business's intention on orientation tends to define their approach (either seeking economic rents or making innovation efforts), and vice versa.

In addition, the homogeneous association between Fraud and Failure structures of frequency distribution by 'Orientation $\times$ Approach' is meaningful. This examination uses control variate of 'type', showing a Cochran-Mantel-Haenszel statistic value of $11.2(\mathrm{df}=1)$, then $\mathrm{p}$-Value $=0.0008$. Thus, the null hypothesis $\mathrm{H}_{0}$ for statistical independence is decisively rejected. So, in general, one could not confirm the major difference between the structured relationships in two categorical data tables.

Subsequently, logistic regressions results are provided. Test statistic values $\left(G^{2}\right.$ and $p$-Value in table 4$)$ reject the $\mathrm{H}_{0}$ for all equations from 2 to 4 .

$$
\begin{aligned}
& \ln (\pi /(1-\pi))=\beta_{0}+\beta_{1} X_{1}+\beta_{2} X_{2} \\
& \ln (\pi /(1-\pi))=\beta_{0}+\beta_{2} X_{2} \\
& \ln (\pi /(1-\pi))=\beta_{0}+\beta_{3} X_{1} X_{2}
\end{aligned}
$$

where $\mathrm{X}_{1}, \mathrm{X}_{2}$ are predictor variables "Rent-seeker" and "Resource Orientation", respectively. The reference categories for these models are Rentseek $=$ 'Rent 0 ', and Resource $=$ 'Res 0 ', in this order.

Table 4. Logistic regression and MLE analysis

\begin{tabular}{ccccc}
\hline & Coefficients & Estimates (s.e.) & G2(p-Value for H0) & $-2 \ln (\mathrm{L})$ \\
\hline Eq.(2) & $\beta_{2}(*)$ & $3.6056(0.4594)$ & $96.0(<0.0001)$ & 148 \\
Eq.(3) & $\beta_{0}(* *) ; \beta_{2}\left(^{*}\right)$ & $-0.5281(0.2629)$ & $95.7(<0.0001)$ & 149 \\
& & $3.6743(0.4466)$ & & 157 \\
Eq.(4) & $\beta_{3}(*)$ & $3.4503(0.4380)$ & $86.8(<0.0001)$ & 150 \\
\hline
\end{tabular}

Notes: The critical value for a $\chi^{2}$-distributed random variable $(\mathrm{df}=1$, proba $=0.01)$ is $6.6349 . \beta_{\mathrm{i}}(*),(* *)$ are statistically significant at 1 and $5 \%$ levels, respectively. (s.e.): Computed standard errors for making appropriate statistical inference.

Table 4 provides estimates and relevant statistics for only significant coefficients, which essentially confirm the hypothetical relationships specified in Eqs. (2-4).

Reported statistics show that Eq. (4) best fits our data, with $-2 \ln (\mathrm{L})$ value being 157 . Given our consideration of both "approach" and "orientation", the Eq. (4) specification enables us to see influence of both through a significant estimate of $\beta_{3}$, at any conventional level.

From the results of Table 4, it is evident that a determination of 'Approach=Rent-seeking' alones does not help explain the outcome, with no $\beta_{0}$ being reported significant in any estimations. That means the fact that a venture chooses to pursue rent-seeking - which is costly to economies (Tullock, 1967; Krueger, 1974; Murphy, Shleifer \& Vishny, 1993) - does not suffice to turn it into a financial scam. But 'Orientation=Resources' does, with $\beta_{2}$ being reported significant at any conventional levels. In these estimations, $\beta_{2}$ are quite large in magnitude too, showing their large influence on explaining type of outcome for the empirical data.

Last, there is an intriguing result coming from the best fit estimation, i.e. Eq.(4). The fact that $\beta_{3}$ is highly significant, and with large magnitude has some important meaning, both theoretically and empirically. It re-confirms the previously reported result of association between orientation of resources and approach of rent-seeking to the extent that their joint effect is quite significant in determining the specific value of outcome Frauds. It is also reasonable to see the separate influence of resources orientation as the single most important and dominating in the cases of Vietnamese financial collapses. However, the genuine frauds have also been influenced by both factors of rent-seeking approach and resource-based orientations before or during the implementing of the business plan.

\section{Conclusions}

Many people are interested in predicting financial collapse, both failures and fraud, and face challenges of availability of data, professional knowledge, and the most important, the performance of an existing financing scheme (e.g., Zmijewski, 1984; Singleton \& Singleton, 2007; Moyer, 1977; Ohlson, 1980). This investigation suggests intuitive and cognitive indications - considering the association of orientation and approach - that 
could help predict ex-ante outcome.

The interdependence of orientation and approach of a business's intention explains increasing numbers of financial collapses in economic turmoil. The existence of innovation does not ensure a successful business but improves creditors/investors' confidence in the entrepreneurial endeavors of fundraisers. Indeed, a neglect of creative performance and reliance on capital and physical resources may lead a business to acute problems caused by the law of diminishing returns (Vuong \& Napier, 2013).

Moreover, lack of innovation, such as the introduction of new products and employment of new technology, prevents business from approaching funding opportunities. In a relationship-based economy, like Vietnam, an entrepreneur has to stand out of the crowd if he wants to attract the society's attention (Vuong \& Tran, 2009).

In addition, it is noteworthy that although traditions of managements often view a business organization as a machine of "information processing", Einstein remins us "information is not knowledge." Therefore, while lots of Vietnamese amateur and professional business people are scrambling for privileded or inside information considered as a type of rent seeking - they trap themselves. Nonaka (1991) affirms that the most single lasting competitive advantage is knowledge, especially "in an economy where the only certainty is uncertainty." In light of this, if a business wants to survive and pursue success then its "sole business" must be "continuous innovation".

The complication of modern economies and the revolution of information technology sometimes confuses people who see innovative traits that may (or may not) be in reality financial frauds. Several confusing examples have appeared in the last few years. When the producer of Thanh Huong Perfume Co. raised funds from relatives, friends, and business-partners in late 1980s, most Vietnamese were unfamiliar with the product. Thus, many believed that the producer possessed some extraordinary technology or knowhow that could generate handsome profits. In 2008, Sacombank's Real Estate Company (Sacomreal) introduced a truly innovative financial product to the infant corporate bond market of Vietnam when it issued corporate bonds that provide bondholders with right to purchase properties developed by the company (Vuong \& Tran 2011). Commercially, that innovative product sold really well, as the instrument met the market need. Naturally, the bond offerings contributed to make Sacomreal one of the most prominent property developers, whose shares have been listed on Ho Chi Minh Stock Exchange. And just recently several IT firms introduced e-commerce to new computer users in their attempts at persuading them to invest in their online-store websites. The perfume producer, the real estate bond market financier, and the IT developers did believe that they were creating some true value.

But they hyped their stories - from the capacity for perfume production, to the market demand for apartments and offices, to the selling power of fancy online stores. Then, when each of these fundraisers faced problems, they in essence tried to set up Ponzi schemes to maintain their performance and ultimately their business failures turned out to be financial frauds. Here, Pressman (1998) is right, again.

The investors were so confident of their assessment of market prospects, the property bubble, and the ecommerce trend that they did not expect or see more deeply into the possibility of fraud. Psychology and the resulting decisions-by greed and scarce business opportunities-may also induce creditors/investors to put their money in risky nests. It is not because of asymmetric information but because of the lack of cost-benefit consideration and careful multi-layer filtering of information (e.g., Vuong \& Napier, 2012) that investors fall prey to the dangers lurking in conditions of turmoil. Despite an appreciation of the credit crunch and economic stagflation, many investors still scramble to withdraw their savings, gather cash from family members and friends, and even to mortgage their houses to lend money and then hope for pretty profits. They innocently ignore the fact that they lent money at sky-high interest rates and that none was able to repay a loan at such rate plus a premium of the usury lenders.

Financial cheaters, on the other hand, well understand the critical effect of psychology. All of their resources, including creativity capability, are employed to build and leverage their close relations to high-ranking bureaucrats, luxury manage their reputations and impressions, and convey the image of successful businesspeople. In reality, some appear to be seeking personal, and perhaps fraudulent, gain.

Last but not least, considering the association of orientation and approach provides potential method of early prediction of the outcomes of a financing scheme. Likewise, it appears that over-tapping available resources and strictly seeking profits to the detriment of investing within the firm in more innovative directions may likely result in collapse. An economic setting of an easing monetary policy and worsening business prospect - for instance, lowering interest rate in association with increasing unemployment - is comfortable environment for financial frauds blossom. In light of this, the economy has to pay for increasing cost of funds, and more important, society's trust is being eroded. Fortunately, entrepreneurship development - to shift business 
orientation to economic prospect - and innovation capacity building - to shift business approach to creativity are possible to pave a pathway out of deadlock situation of this kind.

\section{References}

Agresti, A. (2002). Categorical Data Analysis. Hoboken, NJ: Wiley. http://dx.doi.org/10.1002/0471249688

Avlonitis, G., Papastathopoulou, P. G., \& Gounaris, S. P. (2001). An empirically-based typology of product innovativeness for new financial services: Success and failure scenarios. Journal of Product Innovation Management, 18(5), 324-342. http://dx.doi.org/10.1016/S0737-6782(01)00102-3

Azen, R., \& Walker, C. M. (2011). Categorical Data Analysis for the Behavioral and Social Sciences. New York, NY: Routledge.

Krueger, A. (1974). The political economy of the rent-seeking society. American Economic Review, 64, 291-303.

Moyer, R. C. (1977). Forecasting financial failure: A re-examination. Financial Management, 6, 11-17. http://dx.doi.org/10.2307/3665489

Murphy, K. M., Shleifer, A., \& Vishny, R. W. (1993). Why is rent-seeking so costly to growth? American Economic Review, 83, 409-414.

Napier, N. K., Dang, L. N. V., \& Vuong, Q. H. (2012). It takes two to tango: Entrepreneurship and creativity in troubled times - Vietnam 2012. Sociology Study, 2(9), 662-674.

Nonaka, I. (1991). The Knowledge-Creating Company. Harvard Business Review, Sept-Dec.

Ohlson, J. A. (1980). Financial ratios and the probabilistic prediction of bankruptcy. Journal of Accounting Research, 18, 109-131. http://dx.doi.org/10.2307/2490395

Pressman, S. (1998). On financial frauds and their cause. American Journal of Economics and Sociology, 57, 405-421. http://dx.doi.org/10.1111/j.1536-7150.1998.tb03373.x

Scharfstein, D. S., \& Stein, J. C. (2000). The dark side of internal capital markets: Divisional rent-seeking and inefficient investment. Journal of Finance, 55(6), 2537-2564. http://dx.doi.org/10.1111/0022-1082.00299

Singleton, T. W., \& Singleton, A. J. (2007). Why don’t we detect more fraud. Journal of Corporate Accounting \& Finance, 18, 7-10. http://dx.doi.org/10.1002/jcaf.20302

Tollison, R. D. (1982). Rent seeking: A survey. Kyklos, 35, 575-602. http://dx.doi.org/10.1111/j.1467-6435.1982.tb00174.x

Tullock, G. (1967). The welfare costs of tariffs, monopolies, and theft. Economic Inquiry, 5, 224-232. http://dx.doi.org/10.1111/j.1465-7295.1967.tb01923.x

Vuong, Q. H. (2010). Financial Markets in Vietnam's Transition Economy: Facts, Insights, Implications. Saarbrücken, Germany: VDM-Verlag.

Vuong, Q. H. (2011, July). Vietnam's underground economy: Where "sharks" were food. Stratfor Global Intelligence.

Vuong, Q. H. (2012, August). Vietnam's economic challenges. Stratfor Global Intelligence.

Vuong, Q. H., \& Napier, N. K. (2012). Coffee filters and creativity: The value of multiple filters in the creative process. CEB Working Paper Series.

Vuong, Q. H., \& Napier, N. K. (2013). Resource curse or destructive creation in transition turmoil. China-USA Business Review, 12(5), 486-493.

Vuong, Q. H., Napier, N. K., \& Tran, T. D. (2013). A categorical data analysis on relationships between culture, creativity and business stage: The case of Vietnam. International Journal of Transitions and Innovation Systems, 3, in press.

Vuong, Q. H., Napier, N. K., \& Samson, D. E. (2013). Innovation as determining factor of post-M\&A performance: The case of Vietnam. International Journal of Business and Management, 8(18) (in press).

Vuong, Q. H., \& Tran, T. D. (2009). The cultural dimensions of the Vietnamese private entrepreneurship. IUP Journal of Entrepreneurship Development, 6(3/4), 54-78.

Vuong, Q. H., \& Tran, T. D. (2011). Vietnam's corporate bond market, 1990-2010: Some reflections. Journal of Economic Policy and Research, 6(1), 6-47. 
Zmijewski, M. E. (1984). Methodological issues related to the estimation of financial distress prediction models. Journal of Accounting Research, 22, 59-82. http://dx.doi.org/10.2307/2490859

\section{Copyrights}

Copyright for this article is retained by the author(s), with first publication rights granted to the journal.

This is an open-access article distributed under the terms and conditions of the Creative Commons Attribution license (http://creativecommons.org/licenses/by/3.0/). 